\title{
Micropropagation of Carob (Ceratonia siliqua L.) through Adventitious Buds of Immature Embryonic Cotyledons
}

\author{
Brahim El Bouzdoudi ${ }^{*}$, Rabah Saïdi², Zineb Nejjar El Ansari' ${ }^{1}$, Mohammed L'bachir El Kbiach ${ }^{1}$, \\ Patrick Martin³, Alain Badoc ${ }^{4}$, Ahmed Lamarti1 \\ ${ }^{1}$ Laboratory of Plant Biotechnology, Biology Department, Faculty of Sciences, Abdelmalek Essaadi University, Tetouan, Morocco \\ ${ }^{2}$ Department of Matter and Life Sciences, High Normal School, Martil, Morocco \\ ${ }^{3}$ Chemistry Department, IUT Béthune, F-62408, Artois University, Béthune, France \\ ${ }^{4}$ Axe MIB (Molécules d'Intérêt Biologique), Unité de Recherche Enologie EA 4577, USC 1366 INRA, UFR des Sciences \\ Pharmaceutiques, Université de Bordeaux, ISVV (Institut des Sciences de la Vigne et du Vin), Villenave-d'Ornon, France \\ Email: ^Bchiri2008@gmail.com
}

How to cite this paper: El Bouzdoudi, B., Saïdi, R., El Ansari, Z.N., El Kbiach, M.L., Martin, P., Badoc, A. and Lamarti, A. (2017) Micropropagation of Carob (Ceratonia siliqua L.) through Adventitious Buds of Immature Embryonic Cotyledons. American Journal of Plant Sciences, 8, 2180-2195. https://doi.org/10.4236/ajps.2017.89146

Received: June 24, 2017

Accepted: August 8, 2017

Published: August 11, 2017

Copyright (c) 2017 by authors and Scientific Research Publishing Inc. This work is licensed under the Creative Commons Attribution International License (CC BY 4.0).

http://creativecommons.org/licenses/by/4.0/ c) (i) Open Access

\begin{abstract}
Adventitious budding from embryonic cotyledons of immature seeds of carob was obtained. The combination of BAP $(4.44 \mu \mathrm{M})$ and NAA $(1.5 \mu \mathrm{M})$ furthered the neoformation of adventitious buds. These latter were multiplied on MS medium added with BAP $(2.22 \mu \mathrm{M})$. Stems and leaves growing were improved by adding $2.02 \mu \mathrm{M} \mathrm{GA}_{3}$. Elongation was favored by $0.5 \mu \mathrm{M} \mathrm{NAA}$. $70 \%$ of rooting was obtained with $10 \mu \mathrm{M}$ IBA.
\end{abstract}

\section{Keywords}

Ceratonia siliqua L., Micropropagation, Adventitious Bud, Embryonic Cotyledons

\section{Introduction}

Carob tree (Ceratonia siliqua L., Fabaceae) is an agro-sylvo-pastoral species with socio-economic and ecological interests. It is very adapted to the various Mediterranean climates and different soil types [1] [2] [3].

Carob propagation is carried out in two main ways, by shoot and meristem culture for large-scale clonal propagation and by the development of cell and tissue culture techniques for the induction of calli in vitro.

Traditionally, the propagation of carob trees has been achieved by grafting young trees with selected female buds of productive trees [4]. This traditional 
propagation method has failed to respond to market demand. The carob tree can also be propagated by seedlings, but the seeds do not show correct germination rates unless after scarification; Moreover, this multiplication does not guarantee the sex and the genetic characteristics of the cultivars. Cuttings multiplication is problematic because rooting is difficult [5]. In this context, micropropagation techniques offer an alternative to the propagation of carob trees in order to satisfy the increased demand for this tree [6].

Among the various techniques developed for the in vitro propagation of $\mathrm{Ce}$ ratonia siliqua, we distinguish micropropagation by axillary budding from nodal explants of young stems, and by apex culture [6] [7] [8] or by adventive budding (direct organogenesis on leaf fragments, cotyledons or stems used as explants and indirect when buds appear without or after callus formation) [9], and somatic embryogenesis from immature cotyledons [10], mature cotyledons [11], zygotic embryos [12] or immature seeds [13].

In the present study, embryonic cotyledons culture was established to evaluate organogenic capacity of these explants. Thereby, we tested the effect of different auxins combined with BAP on the development of embryonic cotyledons. Seedlings were regenerated from broken buds; also, several combinations of BAP with NAA were evaluated to improve their organogenicity. Shoot multiplication was studied on MS and WPM mediums added with different growth regulators (auxins, 6-Benzylaminopurine; BAP, and Gibberellic acid; $\mathrm{GA}_{3}$ ) often combined to each other.

\section{Material and Methods}

\subsection{Explants Preparation}

Immature carob fruits were harvested during June 2016, from a female tree on Tetouan-Chefchaouen road, Amtil region, Western Rif, Morocco (Figure 1).

After abundant washing with running water, seeds were placed for 20 minutes in a calcium hypochlorite $\left(\mathrm{Ca}(\mathrm{OCl})_{2}\right)$ solution $(7 \%)$ and then subjected to three

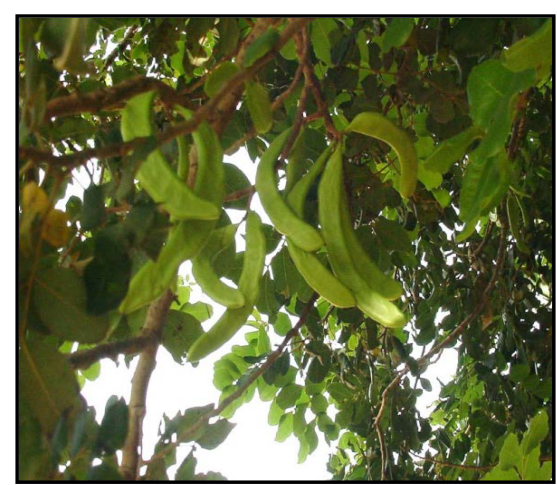

(a)

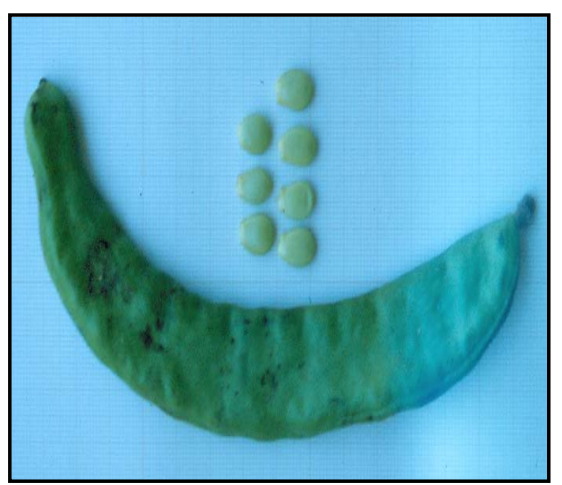

(b)

Figure 1. (a) Female tree with immature seed; (b) Immature pod and seeds harvested in June. 
successive 10 minutes washes with sterilized distilled water. Then, the seeds were removed aseptically under a hood, immersed 3 minutes in mercuric chloride $\left(\mathrm{HgCl}_{2}\right)$ solution $0.1 \%$ and afterward washed three times for 10 minutes with sterile distilled water. These seeds were shelled and separated from their albumen. The lower third of the embryonic cotyledons, with gemmule, plumule and radicle were removed and the upper part was implanted, either horizontally and vertically, in $200 \mathrm{ml}$ flasks containing $50 \mathrm{ml}$ of culture medium, solidified by $0.7 \%$ agar. In addition, the basic nutrient medium consists of Woody Plant Medium (WPM) macronutrients [14], supplemented with Murashige and Skoog (MS) [15] micronutrients and vitamins, as well as $3 \%$ sucrose and $0.1 \mathrm{~g} / \mathrm{l}$ myoinositol, the $\mathrm{pH}$ was adjusted at 5.8. Moreover, cultures were placed in a culture room with 16 hours photoperiod (4000 lux) at $23^{\circ} \mathrm{C}-25^{\circ} \mathrm{C}$ during the day and $20^{\circ} \mathrm{C}$ at night. Results were evaluated after one month growth.

\subsection{Characteristics of Immature Seeds}

A sample of thirty seeds was selected for which the means of length, width and thickness were determined. The weights of fresh (FM) and dry (DM) matter of the seeds were also estimated after drying in an oven at $70^{\circ} \mathrm{C}$ for 15 days (Table 1).

\subsection{Initiation of Embryonic Cotyledons Culture}

\subsubsection{Growth Regulators Effect}

\section{1) Effect of Auxins Associated with BAP}

Embryonic cotyledons were cultured vertically on MS medium supplemented with four auxins (Indole-3-acetic acid; IAA, Indole-3-butyric acid; IBA, 2-naphthalineacetic acid; NAA and 2,4-Dichlorophenoxyacetic acid; 2,4-D) in three concentrations $(0.5 ; 1.5$ and $2.5 \mu \mathrm{M})$ combined with BAP at $4.44 \mu \mathrm{M}$. Results were evaluated after one month.

\section{2) Effect of different concentrations of BAP combined with NAA}

$1.5 \mu \mathrm{M}$ NAA combined with BAP was the best concentration for the development of adventitious buds from embryonic cotyledons. Then we tested other concentrations of BAP $(0.44 ; 1.33 ; 2.22 ; 3.55 ; 4.44$ and $6.66 \mu \mathrm{M})$.

\subsubsection{Effect of the Position of Embryonic Cotyledons}

To test the effect of the position, we tried on to put cotyledons vertically and horizontally in MS medium supplemented with three concentrations of BAP (1.33; 2.22 and $4.4 \mu \mathrm{M}$ ) combined with $1.5 \mu \mathrm{M}$ NAA. Results were reported after one month.

Table 1. Mean dimensions and weights of thirty immature carob seeds harvested in June 2016.

\begin{tabular}{ccccc}
\hline Length $(\mathrm{mm})$ & Width $(\mathrm{mm})$ & Thickness $(\mathrm{mm})$ & FM (g) & DM (g) \\
\hline $10.40 \pm 0.4$ & $7.2 \pm 0.4$ & $3.95 \pm 0.6$ & $0.16 \pm 0.03$ & $0.05 \pm 0.01$ \\
\hline
\end{tabular}




\subsection{Multiplication of Shoots Obtained from Adventitious Buds}

Shoots obtained after the break of adventitious buds from embryonic cotyledons, that presented three internodes of $5-7 \mathrm{~mm}$, were transplanted into different mediums. Results were evaluated after one month growth.

\subsubsection{Effect of Macronutrients MS and WPM}

The effect of MS and WPM macronutrients, supplemented with BAP (2.22; 4.44 and $6.66 \mu \mathrm{M}$ ) was tested on the multiplication of shoots obtained after the break of adventitious buds on the embryonic cotyledons.

\subsubsection{Effect of Growth Regulators}

MS medium, more favorable than WPM for shoot multiplication and survival, was adopted to study the effect of other growth regulators.

Thereby, to study the effect of gibberellins on the multiplication and elongation of shoots obtained from embryonic cotyledons, different concentrations of $\mathrm{GA}_{3}(0.29 ; 0.58 ; 0.87 ; 1.44 ; 2.02$ and $2.89 \mu \mathrm{M})$ were combined with $2.22 \mu \mathrm{M}$ BAP.

Furthermore, different auxins (IAA, IBA, NAA and 2,4-D) at $0.5 \mu \mathrm{M}$, combined with $2.22 \mu \mathrm{M}$ BAP, were tested.

\subsection{Shoot Elongation}

Shoot elongation after multiplication was studied in the presence of three concentrations of BAP $(1.33 ; 2.22$ and $4.44 \mu \mathrm{M})$ and in the presence of $\mathrm{GA}_{3}(0.58$; 1.44 and $2.02 \mu \mathrm{M}$ ) associated to BAP at $1.33 \mu \mathrm{M}$.

\subsection{Plantlets Rooting}

IBA and IAA were adopted to induce shoot rooting after multiplication and elongation. These shoots were first cultured under darkness at $1 / 2 \mathrm{MS}$ medium supplemented with IBA or IAA at 5 or $10 \mu \mathrm{M}$ during one week, then transferred to light in the same medium, but without growth regulators. Results were evaluated after one month.

\subsection{Statistical Analysis}

For each study, three replicates of thirty explants were carried out. All results were analyzed with a completely randomized design and tested using an analysis of variance (ANOVA) and means were compared using Duncan's multiple range test at $p<0.05$.

\section{Results}

\subsection{Embryonic Cotyledons Culture}

\subsubsection{Growth Regulators Effect}

\section{1) Effect of different auxins associated with BAP}

The reaction of embryonic cotyledons varies according to the conditions and the studied parameter. The percentage of only callogenic explants reaches $97 \%$ in the presence of $2,4-\mathrm{D}$ at $2.5 \mu \mathrm{M}$, followed by NAA at $2.5 \mu \mathrm{M}$ with a percentage 
of $92 \%$; moreover, the percentage of callogenic and caulogenic explants is generally low (Table 2, Figure 2). This latter reaches $27.86 \%$ in the presence of $1.5 \mu \mathrm{M}$ NAA, the number of buds per explants is 4.8 . The concentration of $1.5 \mu \mathrm{M}$ seems to be the most appropriate for the neoformation of adventitious buds regardless of the studied auxin, a higher concentration favors callogenesis at the expense of caulogenesis.

\section{2) Effect of different concentrations of BAP combined with NAA}

The combination of BAP at different concentrations with NAA $(1.5 \mu \mathrm{M})$ does not improve the percentage of caulogenic explants. Indeed, the best results are obtained, like before, with $4.44 \mu \mathrm{M}$ BAP. $3.55 \mu \mathrm{M}$ does not present significant difference with $4.44 \mu \mathrm{M}$ BAP (Table 3, Figure 3). In some cases with low concentrations of BAP, roots are formed on the embryonic cotyledons.

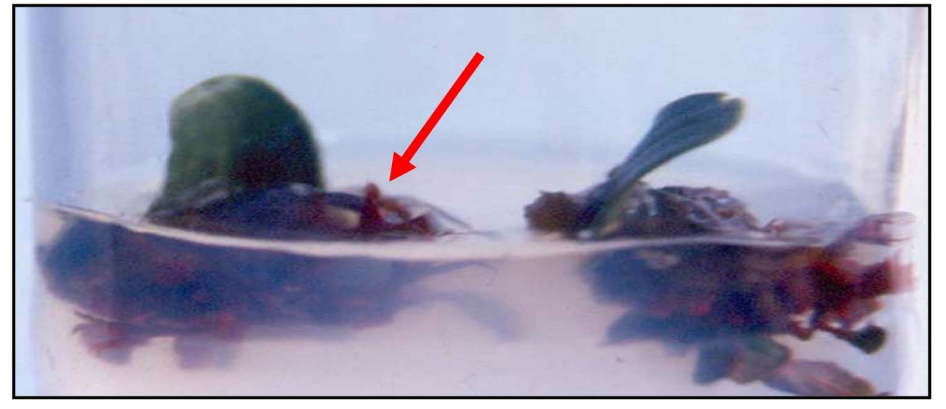

Figure 2. Adventitious buds obtained from embryonic cotyledons cultured in WPM medium added with NAA $(1.5 \mu \mathrm{M})$ combined with BAP $(4.44 \mu \mathrm{M})$, after one month growth.

Table 2. Effect of four auxins combined with BAP $(4.44 \mu \mathrm{M})$ on the morphogenesis of carob embryonic cotyledons after one monthculture.

\begin{tabular}{cccccc}
\hline Auxins & $\begin{array}{c}\text { Concentrations } \\
(\mu \mathrm{M})\end{array}$ & $\begin{array}{c}\text { \% callogenic } \\
\text { explants }\end{array}$ & $\begin{array}{c}\text { \% callogenic and } \\
\text { caulogenic } \\
\text { explants }\end{array}$ & $\begin{array}{c}\text { Number of } \\
\text { buds by } \\
\text { caulogenic explant }\end{array}$ & $\begin{array}{c}\text { \% of explants } \\
\text { without } \\
\text { reaction }\end{array}$ \\
\hline \multirow{2}{*}{ IAA } & 0.5 & $74.20 \mathrm{~g}$ & $6.45 \mathrm{c}$ & $1 \mathrm{c}$ & $19.35 \mathrm{a}$ \\
& 1.5 & $86.30 \mathrm{~cd}$ & $6.80 \mathrm{c}$ & $1 \mathrm{c}$ & $6.90 \mathrm{e}$ \\
& 2.5 & $92.05 \mathrm{~b}$ & $0 \mathrm{e}$ & $0 \mathrm{~d}$ & $7.95 \mathrm{de}$ \\
IBA & 0.5 & $80.77 \mathrm{ef}$ & $0 \mathrm{e}$ & $0 \mathrm{~d}$ & $19.23 \mathrm{a}$ \\
& 1.5 & $77.42 \mathrm{fg}$ & $6.45 \mathrm{c}$ & $1 \mathrm{c}$ & $16.13 \mathrm{~b}$ \\
& 2.5 & $89.50 \mathrm{bc}$ & $0 \mathrm{e}$ & $0 \mathrm{~d}$ & $10.50 \mathrm{c}$ \\
& 0.5 & $82.35 \mathrm{e}$ & $8.55 \mathrm{~b}$ & $2.50 \pm 0.17 \mathrm{~b}$ & $9.10 \mathrm{~cd}$ \\
NAA & 1.5 & $78.57 \mathrm{f}$ & $27.86 \mathrm{a}$ & $4.80 \pm 0.39 \mathrm{a}$ & $3.57 \mathrm{gh}$ \\
& 2.5 & $92.12 \mathrm{~b}$ & $2.70 \mathrm{~d}$ & $1 \mathrm{c}$ & $5.18 \mathrm{fg}$ \\
& 0.5 & $83.33 \mathrm{de}$ & $0 \mathrm{e}$ & $0 \mathrm{~d}$ & $16.67 \mathrm{~b}$ \\
& 1.5 & $86.28 \mathrm{~cd}$ & $6.82 \mathrm{c}$ & $1 \mathrm{c}$ & $6.90 \mathrm{ef}$ \\
& 2.5 & $97.48 \mathrm{a}$ & $0 \mathrm{e}$ & $0 \mathrm{~d}$ & $2.52 \mathrm{~h}$ \\
\hline
\end{tabular}

Means in the same column followed by the same letters are not significantly different from each other according to the Duncan's multiple range test $(p<0.05)$. 


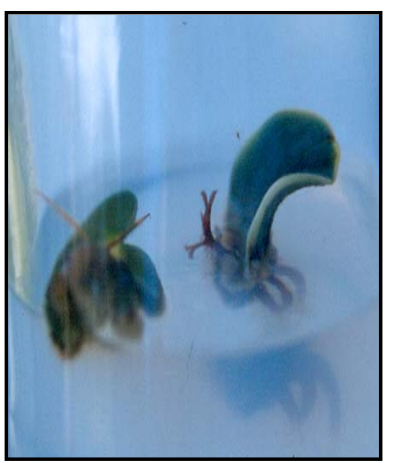

(a)

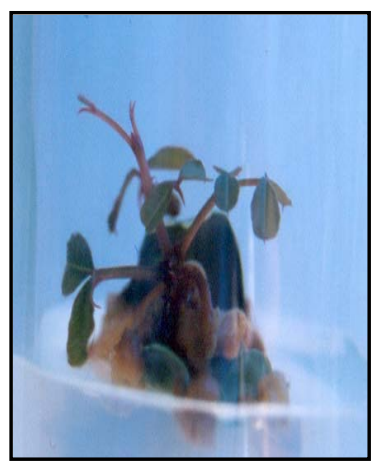

(b)

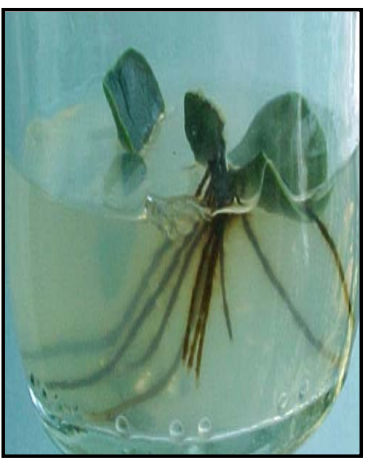

(c)

Figure 3. Effect of different concentrations of BAP combined with NAA. (a) Adventitious buds obtained from embryonic cotyledons cultured in WPM medium, added with NAA $(1.5 \mu \mathrm{M})$ and BAP $(1.33 \mu \mathrm{M})$ after one month growth; (b) Adventitious buds obtained from embryonic cotyledons cultured in WPM medium added with $1.5 \mu \mathrm{M}$ NAA combined with BAP $(4.44 \mu \mathrm{M})$, after one month growth; (c) Rooting of embryonic cotyledons cultured in WPM medium added with NAA $(1.5 \mu \mathrm{M})$ and BAP $(0.44 \mu \mathrm{M})$ after one month growth.

Table 3. Effect of BAP combined with NAA $(1.5 \mu \mathrm{M})$ on the morphogenesis of carob embryonic cotyledons, after one month culture.

\begin{tabular}{ccccc}
\hline BAP $(\mu \mathrm{M})$ & $\begin{array}{c}\text { \% of callogenic } \\
\text { explants }\end{array}$ & $\begin{array}{c}\text { \% of callogenic and } \\
\text { caulogenic explants }\end{array}$ & $\begin{array}{c}\text { Number of buds by } \\
\text { caulogenic explants }\end{array}$ & $\begin{array}{c}\text { \% of explants } \\
\text { without reaction }\end{array}$ \\
\hline 0.44 & $86.67 \mathrm{a}$ & $0 \mathrm{e}$ & $0 \mathrm{e}$ & $13.33 \mathrm{~b}$ \\
1.33 & $76.22 \mathrm{c}$ & $7.92 \mathrm{c}$ & $1.87 \pm 0.17 \mathrm{~d}$ & $15.86 \mathrm{a}$ \\
2.22 & $79.86 \mathrm{bc}$ & $10.04 \mathrm{c}$ & $2.50 \pm 0.21 \mathrm{c}$ & $10.10 \mathrm{c}$ \\
3.55 & $80.95 \mathrm{bc}$ & $14.28 \mathrm{~b}$ & $4.32 \pm 0.35 \mathrm{a}$ & $4.76 \mathrm{~d}$ \\
4.44 & $61.11 \mathrm{c}$ & $28.78 \mathrm{a}$ & $4.50 \pm 0.43 \mathrm{a}$ & $11.11 \mathrm{c}$ \\
6.66 & $85.31 \mathrm{ab}$ & $14.59 \mathrm{~b}$ & $3.02 \pm 0.28 \mathrm{bc}$ & $0 \mathrm{e}$ \\
\hline
\end{tabular}

Means in the same column followed by the same letters are not significantly different from each other according to the Duncan's multiple range test $(p<0.05)$.

\subsubsection{Effect of Embryonic Cotyledons Position}

The position of embryonic cotyledons does not have a remarkable effect on their development (Table 4). Generally, the values obtained are close, with a slight preference for the vertical position, especially for the number of buds by explant, significantly higher at $4.44 \mu \mathrm{M}$.

\subsection{Multiplication of Shoots Obtained from Adventitious Buds}

\subsubsection{Effect of Macronutrients MS and WPM}

The size of shoots varies according to the macronutrients used and the concentration of BAP (Table 5, Figure 4). In WPM medium, the elongation of shoots is maximal at 4.44 and $6.66 \mu \mathrm{M}(1.5 \mathrm{~mm})$, and a similar value without significant difference is obtained at $2.22 \mu \mathrm{M}$ with MS medium.

The neoformation of shoots and leaves seems to be more favorable on MS medium, especially with BAP $2.22 \mu \mathrm{M}$. Similar values are obtained on WPM 


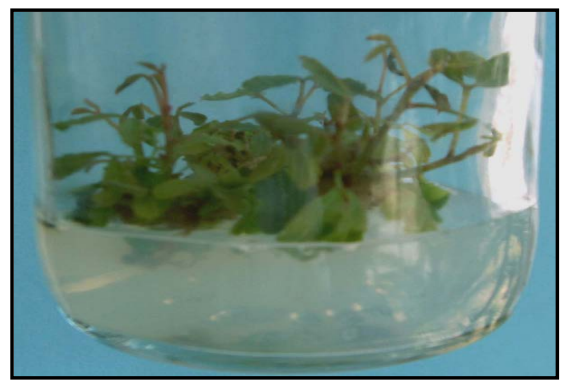

(a)

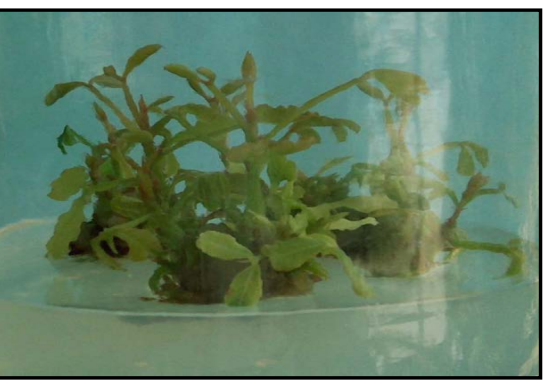

(b)

Figure 4. Effect of macronutrients MS and WPM. (a) Shoots of one month, obtained from adventitious buds deriving from embryonic cotyledons, on MS medium added with BAP $(2.22 \mu \mathrm{M})$; (b) Shoots of one month, obtained from adventitious buds deriving from embryonic cotyledons, on WPM medium added with BAP $(2.22 \mu \mathrm{M})$.

Table 4. Effect of two positions (vertical V and horizontal $\mathrm{H}$ ) on the growth and development of embryonic cotyledons, cultured in WPM medium in presence of NAA (1.5 $\mu \mathrm{M})$ and $\mathrm{BAP}$.

\begin{tabular}{cccccc}
\hline BAP $(\mu \mathrm{M})$ & Position & $\begin{array}{c}\text { \% of callogenic } \\
\text { explants }\end{array}$ & $\begin{array}{c}\text { \% of callogenic } \\
\text { and caulogenic } \\
\text { explants }\end{array}$ & $\begin{array}{c}\text { Number of } \\
\text { buds by caulogenic } \\
\text { explant }\end{array}$ & $\begin{array}{c}\text { \% of explants } \\
\text { without } \\
\text { reaction }\end{array}$ \\
\hline 1.33 & $\mathrm{~V}$ & $73.58 \mathrm{~b}$ & $8.80 \mathrm{bc}$ & $2.31 \pm 0.21 \mathrm{~cd}$ & $17.62 \mathrm{a}$ \\
& $\mathrm{H}$ & $73.35 \mathrm{~b}$ & $7.78 \mathrm{c}$ & $1.65 \pm 0.15 \mathrm{de}$ & $18.72 \mathrm{a}$ \\
& $\mathrm{V}$ & $72.56 \mathrm{~b}$ & $13.81 \mathrm{~b}$ & $3.66 \pm 0.35 \mathrm{~b}$ & $13.64 \mathrm{~b}$ \\
& $\mathrm{H}$ & $80.34 \mathrm{a}$ & $9.64 \mathrm{bc}$ & $2.70 \pm 0.28 \mathrm{c}$ & $10.02 \mathrm{c}$ \\
& $\mathrm{V}$ & $58.10 \mathrm{c}$ & $30.79 \mathrm{a}$ & $5.10 \pm 0.43 \mathrm{a}$ & $11.10 \mathrm{c}$ \\
& $\mathrm{H}$ & $60.60 \mathrm{c}$ & $29.21 \mathrm{a}$ & $1.17 \pm 0.10 \mathrm{e}$ & $10.20 \mathrm{c}$ \\
\hline
\end{tabular}

Means in the same column followed by the same letters are not significantly different from each other according to the Duncan's multiple range test $(p<0.05)$.

Table 5. Effect of two basic medium (MS and WPM) on carob shoot multiplication from adventitious buds after 30 day growth.

\begin{tabular}{|c|c|c|c|c|c|}
\hline & $\begin{array}{l}\text { BAP } \\
(\mu \mathrm{M})\end{array}$ & $\begin{array}{l}\text { Shoots size } \\
(\mathrm{mm})\end{array}$ & $\begin{array}{l}\text { Shoots } \\
\text { number }\end{array}$ & $\begin{array}{c}\text { Number of } \\
\text { leaves by shoot }\end{array}$ & $\begin{array}{c}\% \text { of poorly } \\
\text { developed shoots } \\
(<5 \mathrm{~mm})\end{array}$ \\
\hline \multirow{3}{*}{ WPM } & 2.22 & $12.2 \pm 1.1 \mathrm{c}$ & $3.25 \pm 0.31 \mathrm{c}$ & $2.46 \pm 0.24 c$ & 0 \\
\hline & 4.44 & $14.5 \pm 1.2 \mathrm{ab}$ & $3.34 \pm 0.34 c$ & $3.83 \pm 0.32 \mathrm{a}$ & 0 \\
\hline & 6.66 & $15.1 \pm 1.3 \mathrm{a}$ & $4.00 \pm 0.38 \mathrm{ab}$ & $3.90 \pm 0.35 \mathrm{a}$ & 0 \\
\hline \multirow{3}{*}{ MS } & 2.22 & $15.7 \pm 1.3 \mathrm{a}$ & $4.80 \pm 0.45 \mathrm{a}$ & $3.30 \pm 0.34 b$ & 0 \\
\hline & 4.44 & $13.5 \pm 1.1 \mathrm{bc}$ & $4.52 \pm 0.44 \mathrm{a}$ & $3.01 \pm 0.31 \mathrm{~b}$ & 0 \\
\hline & 6.66 & $12.1 \pm 1.1 \mathrm{c}$ & $3.39 \pm 0.40 \mathrm{ab}$ & $3.75 \pm 0.32 \mathrm{a}$ & 0 \\
\hline
\end{tabular}

Means in the same column followed by the same letters are not significantly different from each other according to the Duncan's multiple range test $(p<0.05)$. 
medium at a high concentration of BAP, however, some physiological disorders were observed, such as the formation of lenticels or the vitrification of explants.

\subsubsection{Effect of Growth Regulators}

\section{1) Effect of $\mathrm{GA}_{3}$}

The combination of $\mathrm{GA}_{3}$ with BAP does not influence strongly shoot growth. Values registered are generally lower than those obtained with BAP alone. Nevertheless, neoformation of shoots and leaves is improved and the best results (6.13 and 3.94, respectively) are obtained with $2.02 \mu \mathrm{M}$ of $\mathrm{GA}_{3}$ (Table 6, Figure 5).

\section{2) Effect of auxins}

The combination of auxins (IAA, IBA and NAA) does not improve significantly shoot elongation. Furthermore, the neoformation of shoots seems to be globally inhibited by the addition of auxins, especially in the case of NAA and 2,4-D, while leaf neoformation increases slightly (Table 7).

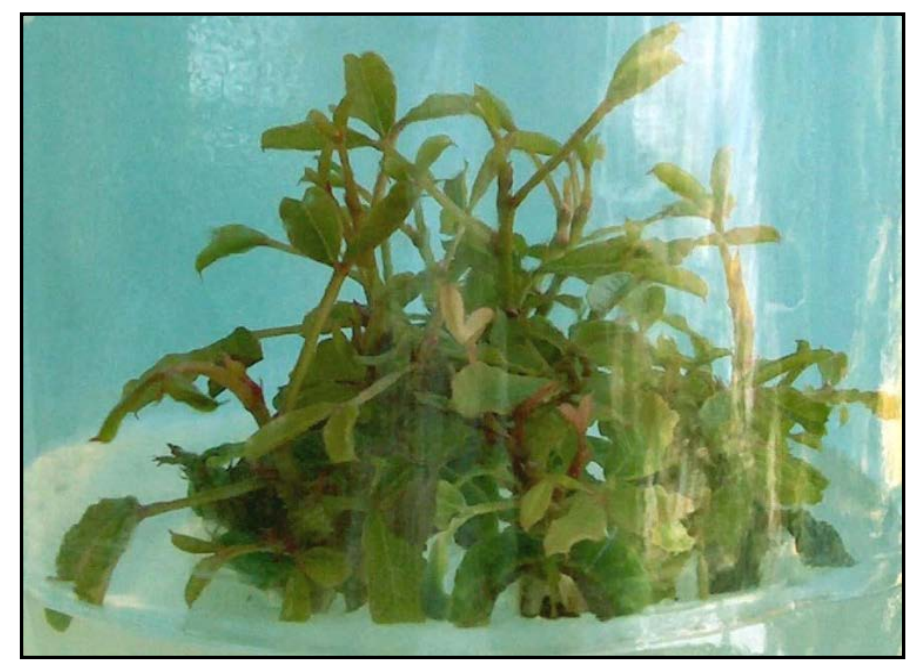

Figure 5. Shoots of one month obtained from adventitious buds deriving from embryonic cotyledons, on MS medium added with $\mathrm{GA}_{3}(2.02 \mu \mathrm{M})$ and BAP $(2.22 \mu \mathrm{M})$.

Table 6. Effect of $\mathrm{GA}_{3}$ combined with BAP $(2.22 \mu \mathrm{M})$ on carob shoot proliferation from adventitious buds after 30 day growth on MS medium.

\begin{tabular}{ccccc}
\hline $\mathrm{GA}_{3}(\mu \mathrm{M})$ & Shoots size $(\mathrm{mm})$ & Shoots number & $\begin{array}{c}\text { Number of } \\
\text { leaves by shoot }\end{array}$ & $\begin{array}{c}\text { \% of shoots } \\
\text { poorly developed }\end{array}$ \\
\hline 0 & $15.1 \pm 1.4 \mathrm{a}$ & $4.80 \pm 0.50 \mathrm{~b}$ & $3.29 \pm 0.30 \mathrm{c}$ & 0 \\
0.29 & $11.7 \pm 1.1 \mathrm{c}$ & $4.68 \pm 0.47 \mathrm{~b}$ & $4.16 \pm 0.38 \mathrm{a}$ & 0 \\
0.58 & $12.1 \pm 1.1 \mathrm{bc}$ & $4.84 \pm 0.45 \mathrm{~b}$ & $3.65 \pm 0.33 \mathrm{~b}$ & 0 \\
1.44 & $13.2 \pm 1.2 \mathrm{bc}$ & $4.99 \pm 0.52 \mathrm{~b}$ & $3.53 \pm 0.34 \mathrm{~b}$ & 0 \\
2.02 & $14.5 \pm 1.3 \mathrm{ab}$ & $6.13 \pm 0.58 \mathrm{a}$ & $3.94 \pm 0.35 \mathrm{a}$ & 0 \\
2.89 & $13.0 \pm 1.2 \mathrm{bc}$ & $5.08 \pm 0.46 \mathrm{~b}$ & $3.62 \pm 0.34 \mathrm{~b}$ & 0 \\
\hline
\end{tabular}

Means in the same column followed by the same letters are not significantly different from each other according to the Duncan's multiple range test $(p<0.05)$. 
Table 7. Effect of four auxins at $0.5 \mu \mathrm{M}$ combined with BAP $(2.22 \mu \mathrm{M})$ on carob shoot multiplication from adventitious buds after 30 day growth on MS medium.

\begin{tabular}{ccccc}
\hline Auxin & Shoots size $(\mathrm{mm})$ & Shoots number & $\begin{array}{c}\text { Number of leaves } \\
\text { by shoot }\end{array}$ & $\begin{array}{c}\% \text { of shoots poorly } \\
\text { developed }\end{array}$ \\
\hline 0 & $15.2 \pm 1.3 \mathrm{ab}$ & $4.76 \pm 0.47 \mathrm{a}$ & $3.36 \pm 0.29 \mathrm{~b}$ & 0 \\
IAA & $15.3 \pm 1.5 \mathrm{ab}$ & $3.67 \pm 0.29 \mathrm{bc}$ & $3.70 \pm 0.35 \mathrm{a}$ & 0 \\
IBA & $15.4 \pm 1.4 \mathrm{ab}$ & $4.21 \pm 0.38 \mathrm{ab}$ & $2.91 \pm 0.28 \mathrm{c}$ & 0 \\
NAA & $16.3 \pm 1.5 \mathrm{a}$ & $3.00 \pm 0.26 \mathrm{c}$ & $3.71 \pm 0.36 \mathrm{a}$ & 0 \\
2,4-D & $13.3 \pm 1.2 \mathrm{~b}$ & $1.35 \pm 0.32 \mathrm{~d}$ & $3.65 \pm 0.55 \mathrm{a}$ & 0 \\
\hline
\end{tabular}

Means in the same column followed by the same letters are not significantly different from each other according to the Duncan's multiple range test $(p<0.05)$.

\subsection{Shoot Elongation}

Shoot elongation is mostly promoted by BAP at $1.33 \mu \mathrm{M}$, but increasing the concentration has a negative effect on their growth. Besides, the addition of $\mathrm{GA}_{3}$ does not improve shoot size. Moreover, an acceleration of growth is observed between the second and the third week, what is translated by a steep slope, which tends to dampen after this period (Figure 6 and Figure 7).

\subsection{Shoot Rooting and Acclimatization of Plantlets}

\subsubsection{Shoot Rooting}

Induction of rooting in the presence of IAA and IBA shows that this latter is the most favorable, especially in $10 \mu \mathrm{M}$, with a maximum percentage of $70 \%$. However, the maximum size of roots is obtained at $5 \mu \mathrm{M}$ of IBA (Table 8, Figure 8).

\subsubsection{Acclimatization of Plantlets}

The acclimatization of the resulted plantlets in the peat is difficult; they often wither during the first week. The success rate did not exceed $40 \%$ (Figure 9).

\section{Discussion}

The culture of embryonic cotyledons of carob tree, established only recently [9], offers a new way of micropropagation. Shoots obtained after multiplication phase are very similar to those obtained by apex culture or by cotyledonary buds culture.

After culturing, embryonic cotyledons, with reduced size (about $7 \mathrm{~mm}$ ), undergo a considerable increase (about $20 \mathrm{~mm}$ ). Generally, a callus develops in the contact of explants with culture medium. The development of adventitious buds is made anarchically within the culture medium. In rare cases, a neoformation of roots is noticed. The percentage of callogenic explants is often high $(74.2 \%$ $97.48 \%)$, while that of callogenic and caulogenic explants is globally low ( $0 \%-$ $27.86 \%)$.

Among the studied auxins, in different concentrations and combined with 


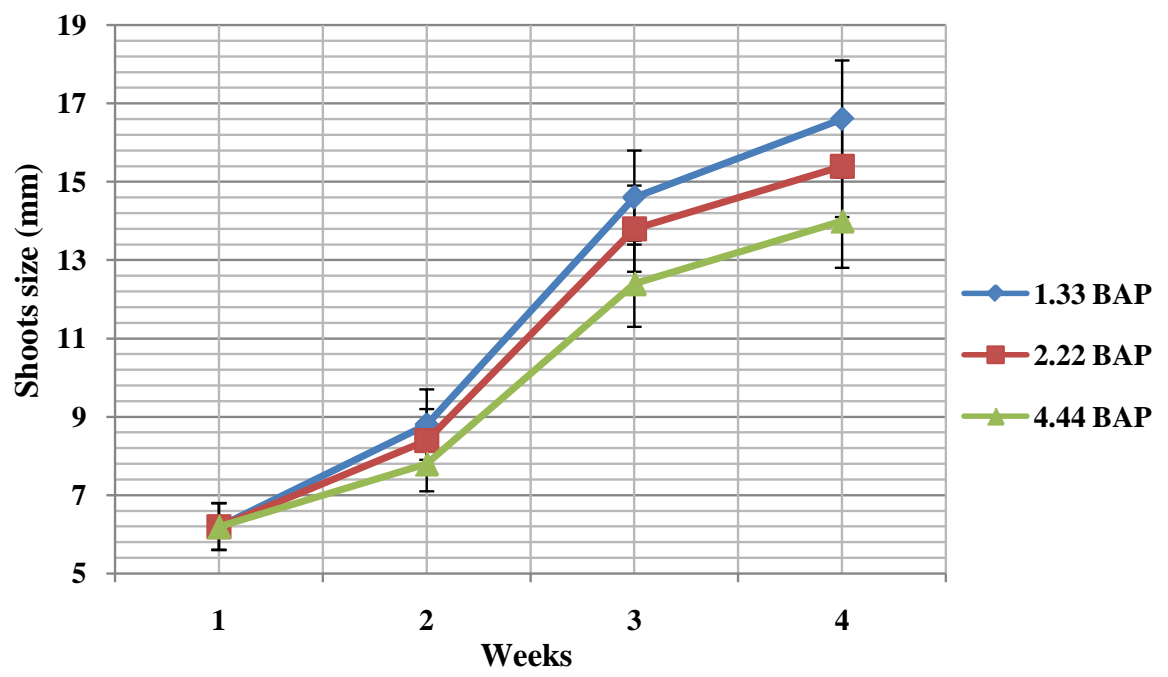

Figure 6. Effect of the concentration of BAP on the elongation of shoots obtained from adventitious buds.

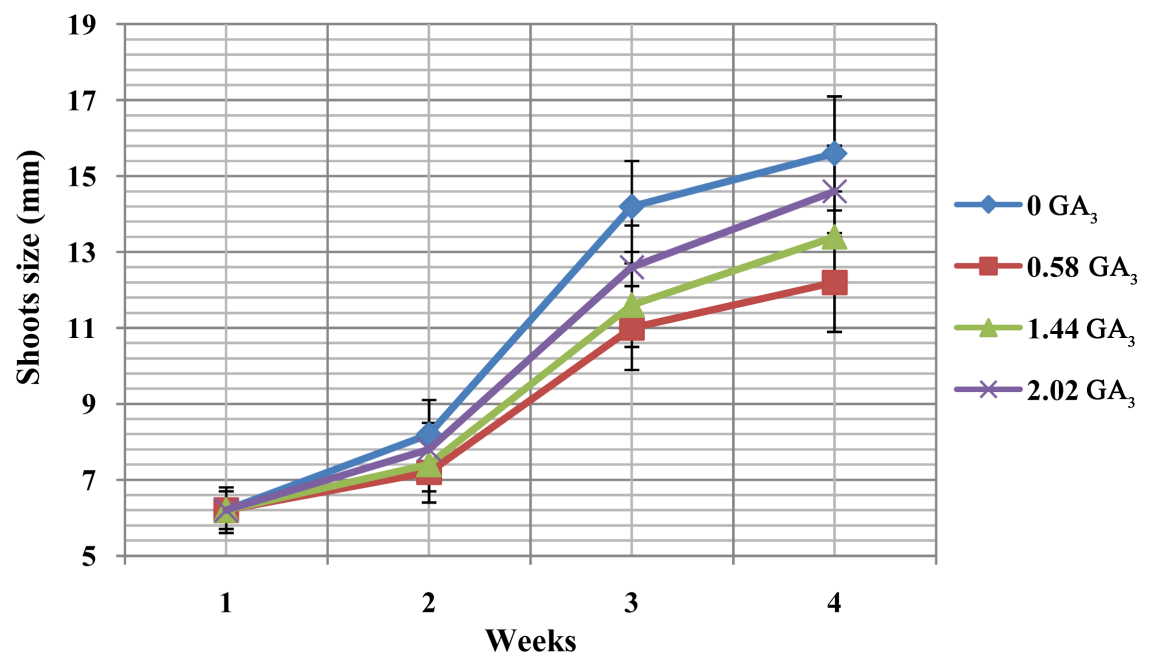

Figure 7. Effect of $\mathrm{GA}_{3}$ combined with BAP $(1.33 \mu \mathrm{M})$ on the elongation of shoots obtained from adventitious buds.

Table 8. Effect of IAA and IBA on carob shoot rooting after one week under dark on $1 / 2$ MS medium, added with auxins (IAA and IBA at 5 and $10 \mu \mathrm{M}$ ) and their transfer to $1 / 2$ MS without auxins, under light.

\begin{tabular}{cccccccc}
\hline Auxins $(\mu \mathrm{M})$ & $\begin{array}{c}\text { Shoots size } \\
(\mathrm{mm})\end{array}$ & $\begin{array}{c}\text { Number of } \\
\text { stems by shoot }\end{array}$ & $\begin{array}{c}\text { Number } \\
\text { of leaves } \\
\text { by shoot }\end{array}$ & $\begin{array}{c}\text { \% of } \\
\text { rooting }\end{array}$ & $\begin{array}{c}\text { Number } \\
\text { of roots by } \\
\text { plantlet }\end{array}$ & $\begin{array}{c}\text { Length } \\
\text { of roots }(\mathrm{mm})\end{array}$ \\
\hline IAA & 5 & $10.8 \pm 1.1 \mathrm{~b}$ & $1.00 \pm 0.0 \mathrm{~b}$ & $4.58 \pm 0.36 \mathrm{~b}$ & $32.45 \mathrm{c}$ & $1.97 \pm 0.20 \mathrm{~b}$ & $28.34 \pm 2.33 \mathrm{c}$ \\
& 10 & $10.4 \pm 0.9 \mathrm{~b}$ & $1.00 \pm 0.0 \mathrm{~b}$ & $3.20 \pm 0.29 \mathrm{c}$ & $25.80 \mathrm{~d}$ & $1.50 \pm 0.45 \mathrm{~b}$ & $25.62 \pm 2.54 \mathrm{c}$ \\
& & & & & & & \\
IBA & 5 & $12.8 \pm 1.1 \mathrm{a}$ & $1.00 \pm 0.0 \mathrm{~b}$ & $4.35 \pm 0.37 \mathrm{~b}$ & $56.20 \mathrm{~b}$ & $3.22 \pm 0.27 \mathrm{a}$ & $43.54 \pm 3.87 \mathrm{a}$ \\
& 10 & $13.9 \pm 1.2 \mathrm{a}$ & $2.45 \pm 0.2 \mathrm{a}$ & $6.50 \pm 0.54 \mathrm{a}$ & $70.37 \mathrm{a}$ & $4.33 \pm 0.36 \mathrm{a}$ & $35.85 \pm 2.65 \mathrm{~b}$
\end{tabular}

Means in the same column followed by the same letters are not significantly different from each other according to the Duncan's multiple range test $(p<0.05)$. 


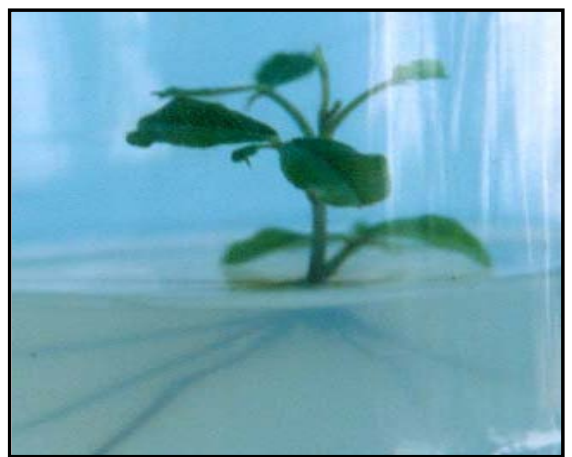

(a)

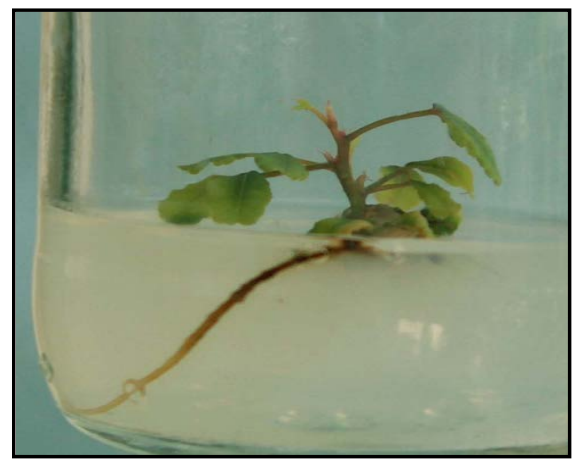

(b)

Figure 8. Rooting phase. (a) Rooted plantlet obtained one month after rooting induction in darkness, on $1 / 2$ MS added with $10 \mu \mathrm{M}$ IBA; (b) Rooted plantlet obtained one month after rooting induction in darkness, on $1 \frac{1}{2} \mathrm{MS}$ added with $5 \mu \mathrm{M}$ IBA.

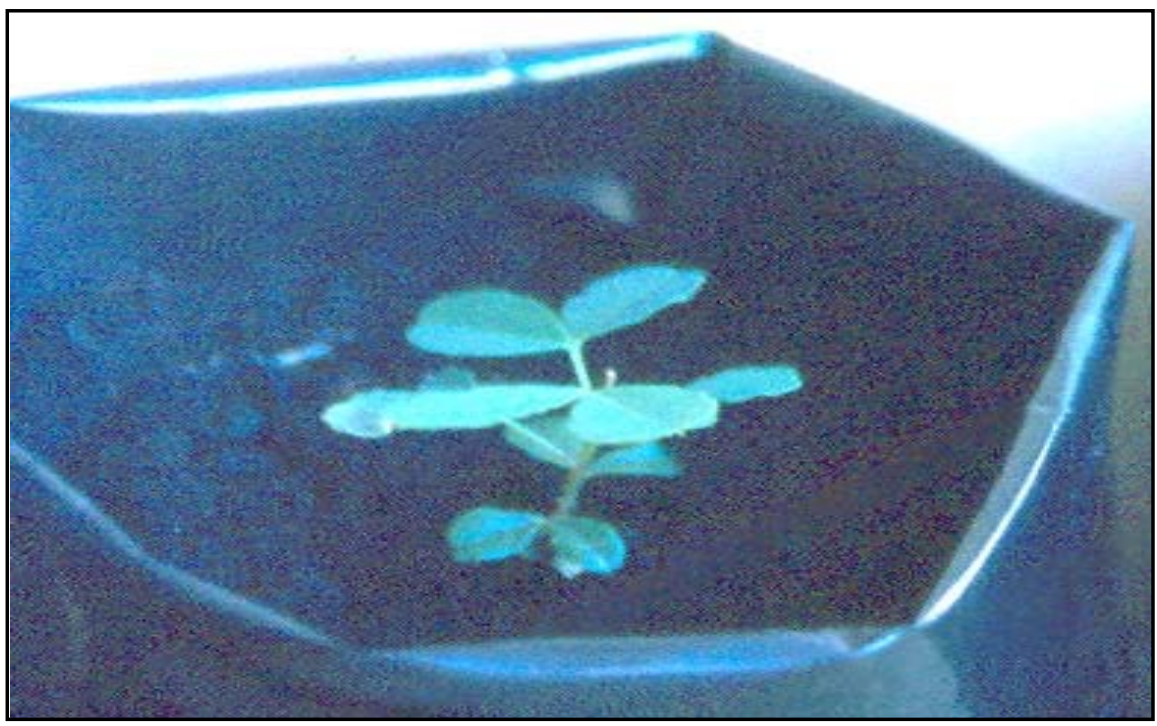

Figure 9. Plantlet obtained after three month acclimatization in peat substrate.

BAP $(4.44 \mu \mathrm{M})$, the neoformation of adventitious buds is mostly favored by NAA at $1.5 \mu \mathrm{M}$, contrary to $2,4-\mathrm{D}$, that favors callogenesis (reaching $97.48 \%$ at $2.5 \mu \mathrm{M}$ ). Indeed, among various types of auxins, 2,4-D is employed in callusing induction [16] [17]. Custódio et al. (2004) [18] obtained the best result in terms of calli induction from anthers, with the higher tested concentration $(2.26 \mu \mathrm{M})$. Also, Carimi et al. (1997) [19] demonstrated that concentrations ranging from 0.45 to $4.52 \mu \mathrm{M}$ promote a good development of callus on cultured ova. Therefore, 2,4-D could induce callogenesis, while NAA could be used to induce both callogenesis and caulogenesis. We also want to point out that the effectiveness of BAP in cotyledonary nodes culture was well indicated and produced better results in multiplication of shoots. However, shoot tips, hypocotyls, cotyledonary leaves and roots produced only callus which were non-regenerative [9].

The combination of NAA $(1.5 \mu \mathrm{M})$ with other concentrations of BAP does not improve the percentage of caulogenic explants. The obtained results are less 
important than those found with $4.44 \mu \mathrm{M}$; beyond this concentration, BAP seems to have an inhibitory effect on the neoformation of adventitious buds. The inhibitory effect of high concentration of BAP was observed in other studies: Belaizi et al. (1995) [20] noticed that during the study of carob regeneration from lateral buds, concentrations higher than $4.44 \mu \mathrm{M}$ does not increase the number of broken buds. As well, Romano et al. (2002) [6] affirm that the best multiple shoot response was obtained in MS medium supplemented with 4.44 $\mu \mathrm{M}$ BAP, for in vitro propagation protocol based on axillary bud proliferation.

Also, survival of meristems reaches the maximum with $8.88 \mu \mathrm{M}$ BAP and decreases in a higher concentration [21]. However, Radi et al. (2013) [22] found that MS medium added with $8.88 \mu \mathrm{M}$ BAP affects significantly the size of shoots obtained from lateral buds and gives the best results among lower concentrations.

The position of embryonic cotyledons on culture medium does not have a considerable effect on their development. The area in contact with the medium reacts by initiating small clusters of callus that will end by forming a big calli accompanied or not by adventitious buds.

Concerning the multiplication and elongation of shoots deriving from adventitious buds, WPM and MS mediums give close results, even if the hormonal balance used is different. The maximum of shoots and leaves is obtained in WPM added with $6.66 \mu \mathrm{M}$ BAP (4 and 3.9, respectively), while close values are obtained in MS medium added with $2.22 \mu \mathrm{M}$ BAP (4.8 and 3.3, respectively). Gharnit and Ennabili (2009) [23] showed that WPM, in comparison with MS and Gresshoff and Doy (GD) [24], added with $0.44 \mu \mathrm{M}$ BAP is the most favorable for the development of explants from shoot tip cultures, with $100 \%$ production of buds, a low rate of apical necrosis and callogenesis.

The addition of $\mathrm{GA}_{3}$ at $2.02 \mu \mathrm{M}$ to BAP $(2.22 \mu \mathrm{M})$ increases slightly the number of shoots and leaves. Thus, $\mathrm{GA}_{3}$ could be added to BAP during shoot multiplication. In fact, Sebastian and McComb (1986) [25] affirmed that addition of $\mathrm{GA}_{3}(2.5 \mu \mathrm{M})$ in the shoot multiplication medium inhibited subsequent rooting. This inhibition was partially overcome by a passage in a medium added with zeatin $(5 \mu \mathrm{M})$ and without $\mathrm{GA}_{3}$. As well, multiple shoots, developed using axillary buds, were regenerated when explants were cultured in MS medium, supplemented with $6.66 \mu \mathrm{M}$ BAP and $1.44 \mu \mathrm{M} \mathrm{GA}_{3}$ [26]. Furthermore, bud break via lateral budding, was ensured with BAP and improved with $2.22 \mu \mathrm{M}$ BAP combined with $1.44 \mu \mathrm{M} \mathrm{GA}_{3}$ [27]. Belaizi et al. (1995) [20] also obtained good results when combining $\mathrm{BAP}$ and $\mathrm{GA}_{3}$, but high concentrations of BAP causes some physiological disorders, like shoot vitrification, apical necrosis, appearance of lenticels and reduction in leaf size.

The combination of auxins with BAP does not improve shoot multiplication. However, auxins like IAA and IBA, in low concentration $(0.57$ and $0.49 \mu \mathrm{M}$, respectively), have been already used, combined with several concentrations of BAP, and sometimes with $\mathrm{GA}_{3}$, with good results when culturing microshoots 
from a tree [28] and using micropropagation by shoot tip cultures [29]. Other studies proved also that high concentrations of auxins combined with BAP and $\mathrm{GA}_{3}$ give good results in the culture of young buds [26], as well as for apical buds break from a mature tree [21]. Radi et al. (2013) [22] observed that the best effect of the combination of auxins and BAP was obtained with 2.22 BAP and 2.46 $\mu \mathrm{M}$ IBA, $2.68 \mathrm{NAA}$, and 2.58 IAA, but the combination of $2.22 \mu \mathrm{M}$ BAP, 2.46 $\mu \mathrm{M}$ IBA and $1.44 \mu \mathrm{M} \mathrm{GA}_{3}$ induced shoot multiplication and also provided rooting of shoots.

Actually, an elongation phase of shoots was added to favor the rooting phase, as in vitro propagation of some other tree species [30] [31]. According to Belaizi et al. (1989) [32], this step is optional and is only required for very small shoots in order to obtain elongated leafy stems of Pyros malus which are then used for rooting. Moreover, after the multiplication phase, small shoots can be directly placed on a rooting medium, but it was proved that the success of this phase depended on the size of the explant. Thus, very short stems (2 to $3 \mathrm{~mm}$ ), placed on a rooting medium containing IBA, showed necrosis very frequently, also, the growth of those who developed roots was blocked subsequently [33]. The same observations were also made by Boxus and Quoirin (1974) [34], IBA applied too early to buds can irreversibly inhibit their elongation. However, after the multiplication phase, the length of new shoots is very variable. In some clones, some buds eventually lengthen after several subcultures and can then be rooted. However, this elongation seems to occur randomly and in most cases, the young shoots do not exceed $5 \mathrm{~mm}$ in length. It is therefore necessary to find a medium allowing the elongation of shoots obtained during the propagation phase, so that they can react to the rhizogenic treatments and then have a normal development [33].

Initiation of shoot rooting after multiplication phase is mostly favored by IBA $(10 \mu \mathrm{M})$ in half strength MS medium, which is in agreement with several other studies [6] [35]. Actually, in many woody plants, IBA is commonly used to promote root initiation [36] [37].

Nevertheless, several authors have shown that auxins are only required during the initiation phase, and become inhibitory for root growth [38] [39] [40]. Also, the effect of mother tree age on rooting of carob shoots was demonstrated: rooting capacity of micro-shoots originated from juvenile parts of mature trees is the best [41]. In some other references, it was reported that carob shoots obtained from shoot tips cultures can root without auxins [23] [29] [42]. Shahzad et al. (2017) [9] reported that IBA promoted rhizogenic response in shoots.

\section{Conclusion}

The results of the present study demonstrate that carob can be cultured in vitro, starting from embryonic cotyledons and going through adventitious buds that develop stems, leaves and roots, to be finally acclimatized with a survival rate of $40 \%$. 


\section{References}

[1] Gullo, M.A. and Salleo, S. (1988) Different Strategies of Drought Resistance in Three Mediterranean Sclerophyllous Trees Growing in the Same Environmental Conditions. New Phytologist, 108, 267-276.

https://doi.org/10.1111/j.1469-8137.1988.tb04162.x

[2] Correia, P.M. and Martins-Loução, M.A. (1994) Preliminary Studies on Mycorrrhizae of Ceratonia siliqua L., Mycorrhizas in Integrated Systems from Genes to Plant Development. New York Botanical Gardens Bronx, NY, 86-88.

[3] Russo, G. and Polignano, G.B. (1996) Variation of Seed and Fruit Characters in Ceratonia siliqua L. Cultivars. Genetic Resources and Crop Evolution, 43, 525-531. https://doi.org/10.1007/BF00138829

[4] Batlle, I. and Tous, J. (1997) Carob Tree. Ceratonia siliqua L. International Plant Genetic Resources Institute, Rome, 92 p.

[5] Lee, C.L., Paul, J.L. and Hackett, W.P. (1977) Promoting of Rooting in Stem Cuttings of Several Ornamental Plants by Pretreatment with Acid or Base. HortScience, $12,41-42$.

[6] Romano, A., Barros, S. and Martins-Loução, M.A. (2002) Micropropagation of the Mediterranean Tree Ceratonia siliqua L. Plant Cell, Tissue and Organ Culture, 68, 35-41. https://doi.org/10.1023/A:1012912504288

[7] Custódio, L., Martins-Loução, M.A. and Romano, A. (2004) Influence of Sugars on in vitro Rooting and Acclimatization of Carob Tree. Biologia Plantarum, 48, 469472. https://doi.org/10.1023/B:BIOP.0000041107.23191.8c

[8] Gonçalves, S., Correia, P.J., Martins-Loução, M.A. and Romano, A. (2005) A New Medium Formulation for in vitro Rooting of Carob Tree based on Leaf Macronutients Concentrations. Biologia Plantarum, 49, 277-280.

https://doi.org/10.1007/s10535-005-7280-4

[9] Shahzad, A., Akhtar, R., Bukhari, N.A. and Perveen, K. (2017) High Incidence Regeneration System in Ceratonia siliqua L. Articulated with SEM and Biochemical Analysis during Developmental Stages. Trees, 31, 1149-1163.

https://doi.org/10.1007/s00468-017-1534-6

[10] Canhoto, J.M., Rama, S.C. and Cruz, G.S. (2006) Somatic Embryogenesis and Plant Regeneration in Carob (Ceratonia siliqua L.). In Vitro Cellular \& Developmental Biology-Plant, 42, 514-519. https://doi.org/10.1079/IVP2006819

[11] Lozzi, A., Abousalim, A. and Abdelwahd, R. (2015) Effet du 2,4-D sur l'Induction de l'Embryogenèse Somatique à partir de Cotylédons Matures de Caroubier (Ceratonia siliqua L.). Revue Marocaine des sciences Agronomiques et Vétérinaires, 3, 24-29.

[12] Custódio, L. and Romano, A. (2006) In vitro Morphogenesis in Zygotic Embryo Cultures of Carob Tree (Ceratonia siliqua L.). Acta Horticulturae, 725, 477-481. https://doi.org/10.17660/ActaHortic.2006.725.68

[13] Ksia, E., Harzallah-Skhiri, F., Verdeil, J.L., Gouta, H., Alemanno, L. and Bouzid, S. (2008) Somatic Embryo Production from Immature Seeds of Carob (Ceratonia siliqua L.): Histological Evidence. The Journal of Horticultural Science and Biotechnology, 83, 401-406. https://doi.org/10.1080/14620316.2008.11512398

[14] McCown, B.H. and Lloyd, G. (1981) Woody Plant Medium (WPM)-A Mineral Nutrient Formulation for Microculture of Woody Plant Species. HortScience, 16, 453-453. 
[15] Murashige, T. and Skoog, F. (1962) A Revised Medium for Rapid Growth and Bioassays with Tobacco Tissue Culture. Physiologia Plantarum, 15, 473-497. https://doi.org/10.1111/j.1399-3054.1962.tb08052.x

[16] Radojevic, I., Marinkovic, N. and Jevremovic, S. (2000) Influence of the Sex of Flowers on Androgenesis in Aesculus hippocastanum L. Anther Culture. In vitro Cellular \& Developmental Biology-Plant, 36, 464-469. https://doi.org/10.1007/s11627-000-0083-6

[17] Chaturvedi, R., Razdan, M.K. and Bhojwani, S.S. (2003) Production of Haploids of Neem (Azadirachta indica A. Juss.) by Anther Culture. Plant Cell Reports, 21, 531537.

[18] Custódio, L., Carneiro, M.F. and Romano, A. (2004) Microsporogenesis and Anther Culture in Carob Tree (Ceratonia siliqua L.). Scientia Horticulturae, 104, 65-77. https://doi.org/10.1016/j.scienta.2004.08.001

[19] Carimi, F., Di Lorenzo, R. and Crescimanno, F.G. (1997) Callus Induction and Somatic Embryogenesis in Carob (Ceratonia siliqua L.) from Ovule Culture. Scientia Horticulturae, 70, 73-79. https://doi.org/10.1016/S0304-4238(97)00034-4

[20] Belaizi, M., Bolen, M.R. and Boxus, P. (1995) Régénération in vitro et Acclimatation du Caroubier (Ceratonia siliqua L.). In: Dubois, J., Ed., Quel Avenir pour I Amélioration des Plantes? John Libbey Eurotext, Paris, 227-232.

[21] Naghmouchi, S., Khoudja, M.L., Agusti Romero, A. and Boussaid, M. (2012) Micropropagation of Carob, Ceratonia siliqua L., by Apex Culture. Acta Botanica Gallica, 159, 357-361. https://doi.org/10.1080/12538078.2012.737124

[22] Radi, A., Echchgadda, G., Ibijbijen, J. and Rochd, M. (2013) In vitro Propagation of Moroccan Carob (Ceratonia siliqua L.). Journal of Food, Agriculture \& Environment, 11, 1103-1107.

[23] Gharnit, N. and Ennabili, A. (2009) Essais Préliminaires de Culture in vitro du Caroubier (Ceratonia siliqua L.) Originaire du Nord Ouest du Maroc. Biomatec Echo, 3, 18-25.

[24] Gresshoff, P.M. and Doy, C.H. (1972) Development and Differentiation of Haploid Lycopersicum esculentum (Tomato). Planta, 107, 161-170.

https://doi.org/10.1007/BF00387721

[25] Sebastian, K.T. and McComb, J.A. (1986) A Micropropagation System for Carob (Ceratonia siliqua L.). Scientia Horticulturae, 28, 127-131. https://doi.org/10.1016/0304-4238(86)90132-9

[26] Hakim, L., Islam, M.R., Mamun, A.N.K., Ahmed, G. and Khan, R. (2010) Clonal Propagation of Carob (Ceratonia siliqua L., Fabaceae). Bangladesh Journal of Botany, 39, 15-19. https://doi.org/10.3329/bjb.v39i1.5520

[27] Saïdi, R., Lamarti, A. and Badoc, A. (2007) Micropropagation du Caroubier (Ceratonia siliqua) par Culture de Bourgeons Axillaires issus de Jeunes Plantules. Bulletin de la Société de Pharmacie de Bordeaux, 146, 113-129.

[28] Thomas, V. and Mehta, A.R. (1983) Effect of Phloroglucinol on Shoot Growth and Initiation of Roots in Carob Tree Cultures Grown in Vitro. In Sen, S.K. and Giles, K.L., Eds., Plant Cell Culture in Crop Improvement. Plenum Press, New York, 451457. https://doi.org/10.1007/978-1-4684-4379-0_49

[29] Saïdi, R., El Bouzdoudi, B., Kbiach, M.B., Lamarti, A. and Maouni, A. (2015) Effets des Macroéléments et des Auxines sur la Micropropagation du Caroubier (Ceratonia siliqua L., Leguminosae) par Culture d'Apex. Journal of Materials and Environmental Sciences, 6, 2330-2337. 
[30] Victório, C.P., Salgueiro Lage, C.L. and Sato, A. (2012) Tissue Culture Techniques in the Proliferation of Shoots and Roots of Calendula officinalis. Revista Ciência Agronômica, 43, 539-545. https://doi.org/10.1590/S1806-66902012000300017

[31] Sadeghi, F., Yadollahi, A., Jafarkhani Kermani, M. and Eftekhari, M. (2015) Optimizing Culture Media for in vitro Proliferation and Rooting of Tetra (Prunus empyrean 3) Rootstock. Journal of Genetic Engineering and Biotechnology, 13, 19- 23. https://doi.org/10.1016/j.jgeb.2014.12.006

[32] Belaizi, M., Sangwan, R.S., David, A. and Sangwan-Norreel, B.S. (1989) Maîtrise des étapes de la micropropagation du Pommier (Pyrus malus) L. cv. Golden Delicious, Bulletin de la Société Botanique de France. Lettres Botaniques, 136, 187-197.

[33] Riffaud, J.L., Cornu, D. and Capelli, P. (1981) Utilisation de la Culture in vitro Pour la Multiplication de Merisiers Adultes (Prunus avium L.) Sélectionnés en Forêt. Agronomie, EDP Sciences, 1, 633-640. https://doi.org/10.1051/agro:19810804

[34] Boxus, P. and Quoirin, M. (1974) La Culture de Méristèmes Apicaux de quelques Espèces de Prunus. Bulletin de la Société Royale de Botanique de Belgique, 107, 91 101.

[35] Saïdi, R., Wahby, I. and Lamarti, A. (2003) Multiplication in vitro du Caroubier (Ceratonia siliqua L.) par Culture des Bourgeons. Proceedings of $3^{\text {ème }}$ Congrès National de Génétique et Biologie Moléculaire, Tanger Maroc, 98 p.

[36] Onay, A., Pirinc, V., Adiyaman, F., Işikalan, Ç., Tilkat, E. and Başaran, D. (2003) In Vivo and in vitro Micrografting of Pistachio, Pistacia vera L. cv. Turkish Journal of Biology, 27, 95-100.

[37] Bhatt, I.D. and Dhar, U. (2004) Factors Controlling Micropropagation of Myrica esculenta buch. -Ham. ex D. Don: a High Value Wild Edible of Kumaun Himalaya. African Journal of Biotechnology, 3, 534-540. https://doi.org/10.5897/AJB2004.000-2097

[38] Shwab, L. and Martins-Loução, M.A. (1988) Shoot Formation in Ceratonia siliqua Hypocotyls Callus. Proceedings of the 2nd International Carob Symposium, Valencia, 29 September-1 October 1987, 245-253.

[39] El Hamdouni, E.M., Lamarti, A. and Badoc, A. (2000) Micropropagation des Cultivars 'Chandler' et 'Tudla' de Fraisier (Fragaria X ananassa Duch.). Bulletin de la Société de Pharmacie de Bordeaux, 139, 91-104.

[40] Chalupa, V. (2002) In vitro Propagation of Mature Trees of Sorbus aucuparia L. and Field Performance of Micropropagated Trees. Prague Czech Academy of Agricultural Sciences, 48, 529-535.

[41] Naghmouchi, S., Khouja, M.L., Rejeb, M.N. and Boussaid, M. (2008) Effect of Growth Regulators and Explant Origin on in vitro Propagation of Ceratonia siliqua L. via Cuttings. Biotechnologie, Agronomie, Société et Environnement, 12, 251-258.

[42] Vinterhalter, D. and Vinterhalter, B. (1992) Factors Affecting in vitro Propagation of Carob (Ceratonia siliqua L.). Archives of Biological Sciences, 44, 177-186. 
Submit or recommend next manuscript to SCIRP and we will provide best service for you:

Accepting pre-submission inquiries through Email, Facebook, LinkedIn, Twitter, etc. A wide selection of journals (inclusive of 9 subjects, more than 200 journals)

Providing 24-hour high-quality service

User-friendly online submission system

Fair and swift peer-review system

Efficient typesetting and proofreading procedure

Display of the result of downloads and visits, as well as the number of cited articles Maximum dissemination of your research work

Submit your manuscript at: http://papersubmission.scirp.org/

Or contact ajps@scirp.org 